\title{
新規骨格構築法を基盤とする縮環生物活性天然物の合成研究
}

\author{
山越博幸
}

\section{Studies on the Syntheses of Bioactive Natural Products Having a Fused Ring System Based on Novel Skeletal Construction Methods}

\author{
Hiroyuki Yamakoshi ${ }^{\dagger}$ \\ Graduate School of Pharmaceutical Sciences, Nagoya City University; \\ 3-1 Tanabe-dori, Mizuho-ku, Nagoya 467-8603, Japan.
}

(Received May 28, 2021)

\begin{abstract}
Here, I describe a part of our efforts to develop synthetic strategies to construct bioactive natural products having a fused ring system. We have designed four chiral building blocks bearing contiguous quaternary stereocenters for the syntheses of bioactive C17-oxygenated steroids/triterpenoids and C9-oxygenated labdane diterpenoids. The compounds were stereoselectively synthesized from $\alpha$-substituted glycolic acid $(R)$-3-methylcyclohex-2-enyl esters through IrelandClaisen rearrangement to construct the stereocenters simultaneously. Synthetic utility of a $\beta$-type building block is highlighted by total syntheses of marrubiin (11 steps, 22\%) and related seven labdane diterpene lactones, cyllenine C (12 steps, 29\%), marrulactone (13 steps, 11\%), marrulanic acid (14 steps, 10\%), marrubasch F (12 steps, 14\%), marrulibacetal (14 steps, 4\%), marrulibacetal A (14 steps, 2\%), and desertine (15 steps, $0.5 \%$ ). These syntheses feature the construction of the [6.6.5] -tricyclic ring portion via a Pauson-Khand reaction, cleavage of the resultant cyclopentenone ring and an elongation of the C9 side chain by an epoxide opening reaction. The relative stereochemistry of desertine was determined to be $13 R, 14 S, 15 S, 16 R$ by some chemical conversions and NMR analysis. Further efforts toward total syntheses of oxygenated terpenoids using three other chiral building blocks and structure-activity relationship study of synthesized labdane diterpene lactones are currently underway in our laboratory and will be reported in due course.
\end{abstract}

Key words_— natural product synthesis; building block; oxygenated terpenoid; labdane; marrubiin

\section{はじめに}

医薬品資源として有望な化合物の物質供給を可能 とする合成経路の確立は, 有機合成化学に課せられ た重要な課題の 1 つである，筆者らは，縮環生物活 性化合物の骨格構築に利用可能な方法論の開発に焦 点を当て, 同群天然物の全合成研究に取り組んでき た. 本稿では, 筆者らが展開している合成研究の 1 つ，「新規キラル合成ブロックの創製を基盤とする 酸化型テルペノイドの合成」について述べる.

1. 酸化型テルペノイドに含まれる共通モチーフ ステロイドやトリテルペノイドの C17 位やラブ

名古屋市立大学大学院薬学研究科（开467-8603 名古屋 市瑞穂区田辺通 3-1)

現所属: †東北大学大学院薬学研究科医薬品開発研究セ ンター/中央機器室（下980-8603 仙台市青葉区荒巻字 青葉 6-3)

e-mail: hiroyuki.yamakoshi.e1@ tohoku.ac.jp

本総説は, 2020 年度日本薬学会東海支部学術奨励賞の

受賞を記念して記述したものである.
ダンジテルペノイドの C9 位は酸化を受け易く，こ の位置が酸化された天然物（以下, 酸化型テルペ) イドと略す）が数多く報告されている. Figure 1 に 示したシラシロシド E-1 (1), 1) カドコッシラクトン $\left.\mathrm{A}(2),{ }^{2}\right)$ マルリブアセタール (3) ${ }^{3)}$ など, 生物活性 を示すものも含まれていることから，同群化合物を 合成する手法の開発は創薬化学的に重要である，本 化合物群の合成上の課題としては, 多環式骨格の構 築と酸素官能基を含む第四級不斉中心 (C17 or C9) の立体選択的構築が挙げられる. 従来, 同群化合物 を合成する際には, Robinson 環化やポリエン環化 などで調製した多環式化合物を原料として，必要な 官能基を順次導入する手法が採られてきた（Fig. 2).一方，筆者らは，二連続第四級不斉中心を持 ち, 酸素原子の置換した不斉中心の立体化学が異な る $\alpha$ 型, 又は $\beta$ 型の共通モチーフのどちらかが酸 化型テルペノイドには含まれていることに着目し, 同モチーフを含む化合物をキラル合成ブロックとし 

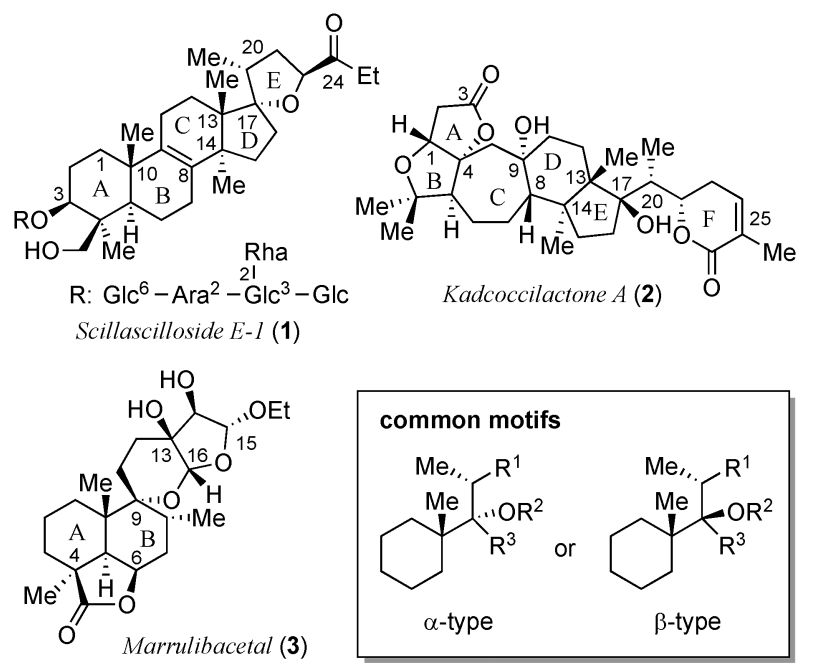

Fig. 1. Structures of C17 (C9)-Oxygenated Terpenoids

$$
\text { cyclization construction of } \mathrm{C} 17 \text { (or C9) stereocenter }
$$

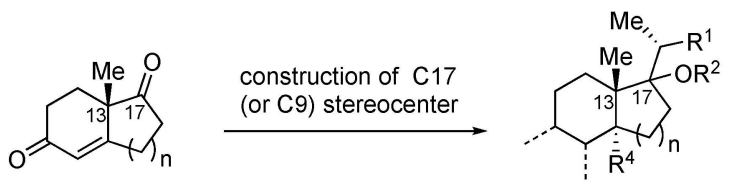

fused rings C17 (or C9)-oxygenated terpenoid

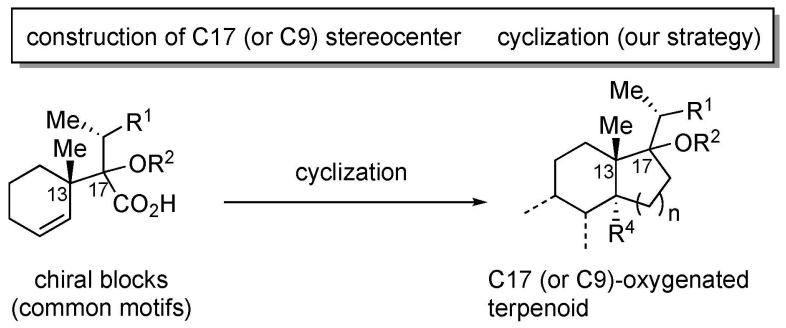

Fig. 2. Synthetic Strategies for Oxygenated Terpenoids

て創製することを考えた。本合成ブロックから環形 成を経て酸化型テルペノイドに誘導できれば，従来 法とは異なる経路での全合成が実現できると期待さ れる。 そこで筆者らは，Fig. 3 に示した 4 種のキラ ル合成ブロック 4-7 をデザインし， $\alpha$ 置換グリコー ル酸エステルの Ireland-Claisen 転位による二連続 第四級不斉中心の一段階構築を鍵工程として，同ブ ロックの合成に着手した。

\section{2. キラル合成ブロックの合成}

まず，文献既知のエポキシアルコール 8 から 5 工 程で環状構造を持たないカルボン酸由来のエステル 9 を調製し, Ireland-Claisen 転位を試みた (Scheme 1). キレーション制御により $Z$ 体のシリルケテン
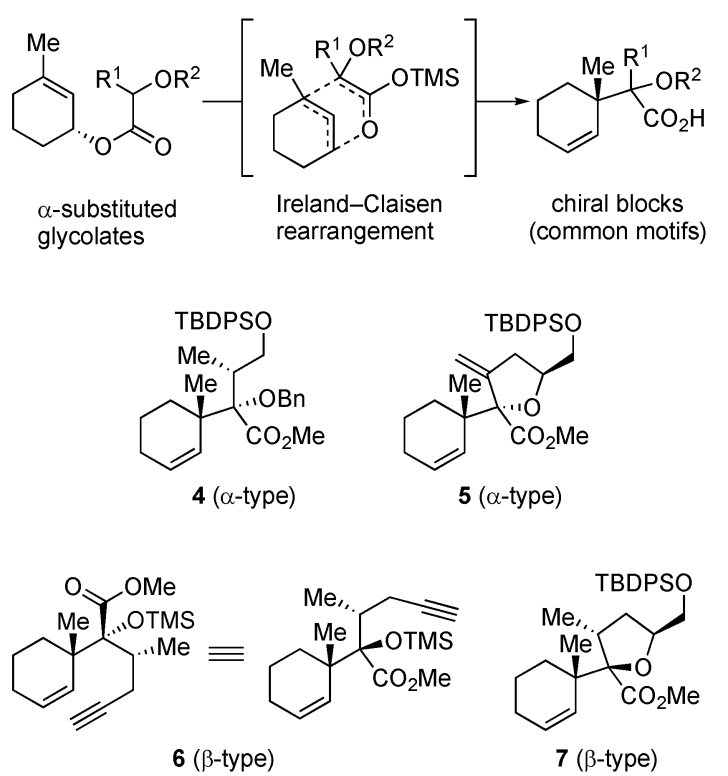

Fig. 3. Structures of Chiral Building Blocks

アセタールを生成させて室温まで昇温すると，反応 はいす形遷移状態 $\mathbf{1 0}$ を経て進行し， $\alpha$ 型のカルボ ン酸 11 が立体選択的に得られた（異性体比 94 ： 6). 本化合物をメチルエステルへと変換することで, $\alpha$ 型ブロック 4 を合成できた. ${ }^{4)}$

シラシロシド E-1（1）のように，C17 位に酸素五 員環がスピロ結合した天然物が存在する。そこで, THF 環を持つカルボン酸由来のエステル 13 を文献 既知のラクトン 12 から 8 工程で調製した。 エステ ル 9 と同じ条件下に附したところ， $\beta$ 型のカルボン 酸 16 が $96: 4$ の立体選択性で優先的に生成した. THF 環上のメチル基とシクロヘキセン環の間に立 体反発が生じ，通常は有利ないす形遷移状態 15 の 形成が妨げられ，反応は舟形遷移状態 14 を経て進 行したと考えられる。得られたカルボン酸 16 を $O$ メチル化することで，THF 環を持つ $\beta$ 型ブロック 7 を合成できた．また，化合物 7 は，TBDPS 基の除 去と生じたアルコールの塩素化により塩化物 $\mathbf{1 8}$ へ

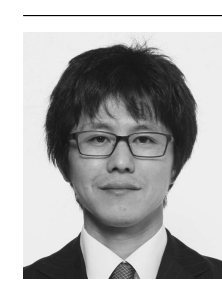

山越博幸
東北大学大学院薬学研究科医薬品開発 研究センター/中央機器室 助教, 博士 (薬学). 2010 年東北大学大学院薬学研 究科博士課程修了 (岩㴊好治教授), 2010-2013 年 ERATO 袖岡生細胞分子 化学プロジェクト博士研究員（袖岡幹 子総括)，2013-2020 年名古屋市立大学 大学院薬学研究科 助教 (中村精一教授), 2020 年 7 月より現職. 

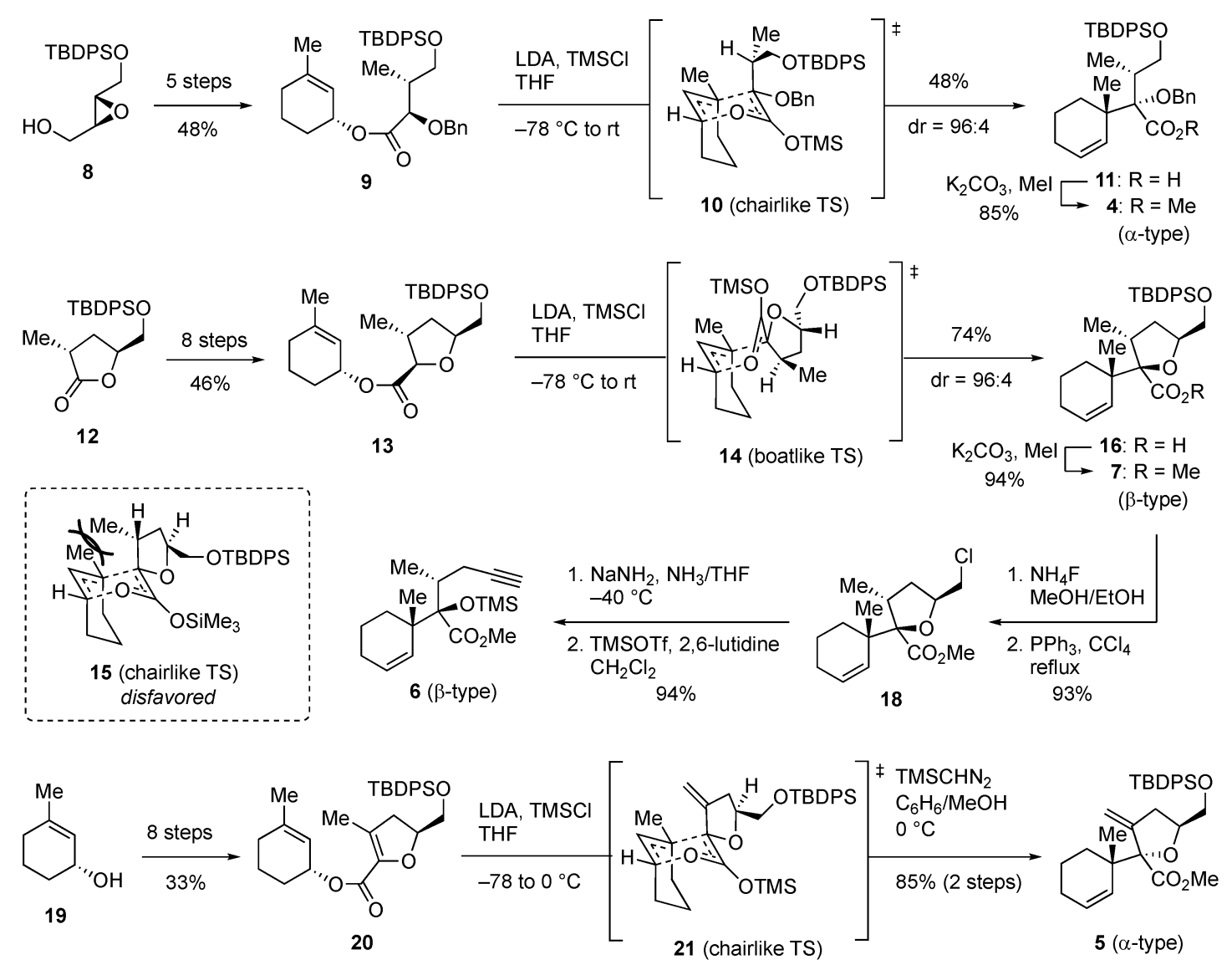

Scheme 1. Syntheses of Chiral Building Blocks

と導いた後, ナトリウムアミドを作用させて THF 環を位置選択的に開環することで, 鎖状の $\beta$ 型ブ ロック 6 への誘導が可能であつた. ${ }^{5)}$

以上の結果を踏まえると，THF 環を持つエステ ルを基質とした場合にも，環上のメチル基に起因す る立体障害を軽減すればいす形遷移状態を経て転位 が進行すると予想される。そこで，THF 環上 3 位 を $\mathrm{sp}^{2}$ 炭素に変更した基質 $\mathbf{2 0}$ をデザインし, 文献 既知のアリルアルコール19から 8 工程で調製し た. エステル 20 の Ireland-Claisen 転位を試みた結 果, 予想通りいす形遷移状態 21 を経て反応が進行 し，ほぼ完璧な立体選択性で環状の $\alpha$ 型ブロック 5 を得ることに成功した。 ${ }^{6}$

開発した合成ブロック 4-7 の有用性を示すため, 筆者らは次に天然物合成への応用に着手した。 現在 までに，鎖状の $\alpha$ 型ブロック 4 からは OSW-17)の $\mathrm{CD}$ 環部, 環状構造を持つ $\alpha$ 型ブロック $\mathbf{5}$ からはシ ラシロシド E-1 (1) の CDE 環部, 6) 鎖状の $\beta$ 型ブ ロック6からはカドコッシラクトン $\mathrm{A}(2)^{2)}$ の $\mathrm{DE}$ 環部, 環状構造を持つ $\beta$ 型ブロック 7 からは 8 種

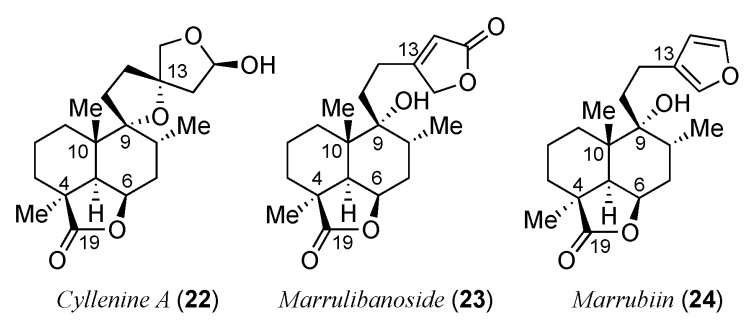

Fig. 4. Bioactive Labdane Diterpene Lactones

のラブダンジテルペンラクトン類を全合成すること ができた. ${ }^{8,9)}$ 誌面の都合上, 本稿ではラブダンジテ ルペンラクトン類の全合成に絞り, 詳細を述べる.

\section{3. マルビインの全合成}

二ガハッカ属植物からは C9 位が酸化されたラブ ダンジテルペンラクトンが数多く見い出されてい る。その中には, 鎮㾏作用物質マルリブアセタール (3) ${ }^{3)}$ や抗腫瘍性化合物シレニン A (22), ${ }^{10)}$ 抗炎症活 性化合物マルリバノシド $(\mathbf{2 3})^{11)}$ など, 多彩な生物 活性化合物が含まれる（Fig. 4)。二ガハッカの主 要な苦味成分として知られるマルビイン（24）は, その代表的な化合物であり, 鎮痤活性や鎮痛活性な 


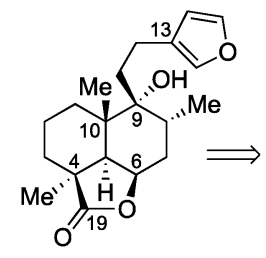

Marrubiin (24)

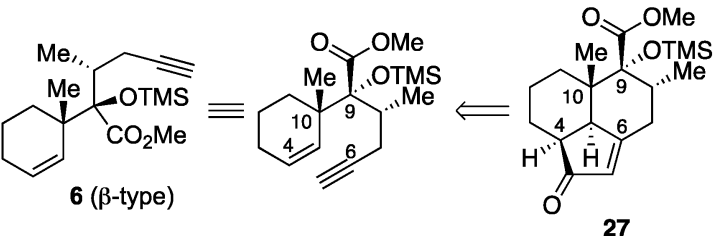

Scheme 2. Retrosynthetic Analysis of Marrubiin (24)

ぞ，様々な生物活性を示す. ${ }^{12)}$ 本化合物の化学合成 に関する報告は，Mangoni らのラセミ体での全合 成一例のみである.13) そこで筆者らは，キラル合成 ブロック 6 を中間体とするマルビイン（24）の全合 成研究に着手した。

筆者らはScheme 2 に示した逆合成解析を行っ た。マルビインと C9 位側鎖部の異なる類縁天然物 を網羅的に合成することを想定し，天然物の側鎖部 を，有機金属試薬を用いたエポキシドの開環反応に より合成の終盤に導入することにした。 その前駆体 となるエポキシド 25 は，ラクトン構造を持つエス テル 26 を官能基選択的に還元できれば合成可能で ある. C4 位のメチル基はエノラートのアルキル化 により立体選択的に導入されると予測される。ここ で，ラクトン環を持つ化合物 $\mathbf{2 6}$ をキルル合成ブ ロックから得るためには，C4 位でのカルボキシ化， C5-C6 位間の結合形成，並びに C6 位アルキン部で の炭素炭素結合の酸化開裂が必要となる。そこで,

Pauson-Khand 反応により環構造を構築して三環性 化合物 27 を得た後，シクロペンテノン環を酸化的 に開裂させることを計画した。

まず，アルキン 6 をコバルト錯体 28 に変換し， Pauson-Khand 反応を検討した結果，杉原らの報 告14)に従ってシクロヘキシルアミンを反応促進剂と して用いた場合に所望のトランスデカリン骨格を含 む三環性化合物 $\mathbf{2 7}$ が単一異性体として得られるこ とを見い出した（Scheme 3)，分子間反応に由来す る副生成物がみられたことから，高希釈条件下で反 応を試みたところ，10 mM まで希釈した場合に副

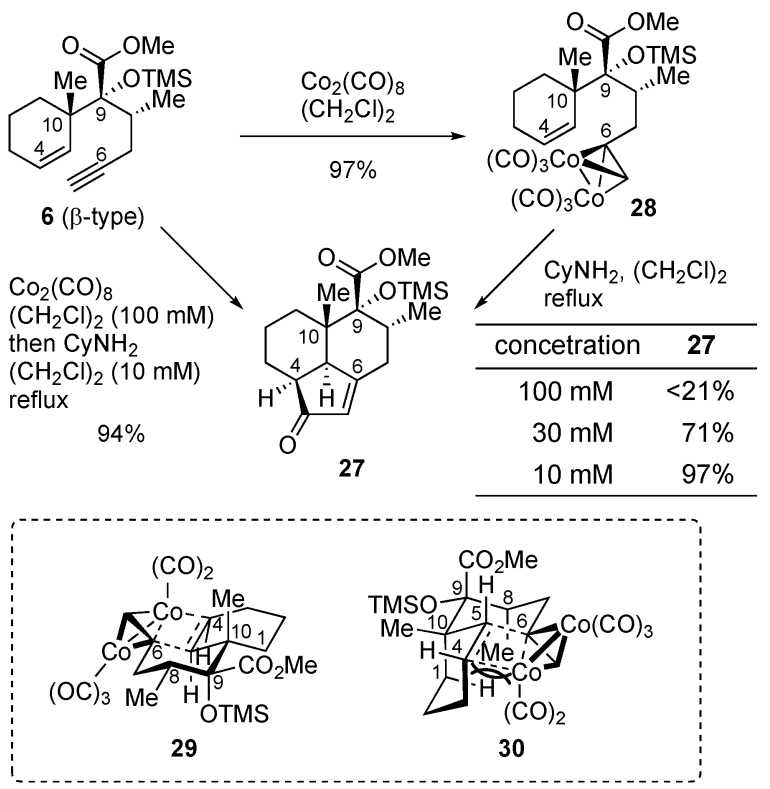

Scheme 3. Pauson-Khand Reaction for the Formation of Tricyclic Compound 27

生成物がほとんど観察されなくなり，収率 $97 \%$ で 目的物を得ることができた。なお，錯体形成と環化 反応をワンポット化することは可能であり，アルキ ン 6 に $\mathrm{Co}_{2}(\mathrm{CO})_{8}$ を作用させてコバルト錯体 28 を 形成後, $\left(\mathrm{CH}_{2} \mathrm{Cl}\right)_{2}$ と $\mathrm{CyNH}_{2}$ を加えて加熱還流する

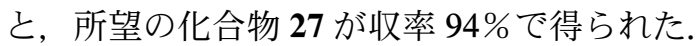

Pauson-Khand 反応の生成物の立体化学は，コバ ルタサイクルの形成段階で決定される. ${ }^{15)}$ シスデカ リン型生成物を与える遷移状態 $\mathbf{3 0}$ においては，ア キシアル位を占める C8 位メチル基と C1 位水素原 子の間に大きな立体反発が生じる。そのため, 反応 は遷移状態 29 を経て進行し，トランスデカリン環 を含む生成物 $\mathbf{2 7}$ が立体選択的に得られたと考えら れる。

得られた化合物 27 の $\mathrm{C} 4$ 位をメチル化後, シク ロペンテノン環の酸化開裂を試みた（Scheme 4). ルテニウム酸化では複雑な混合物となり，オスミウ ム酸化では原料回収に終わった。一方，オゾン酸化 を行った場合には，望みのカルボン酸 32 が収率 $22 \%$ で得られた。 また，本反応で生じた他の化合物 を解析した結果， $\alpha$-ケト酸 $\mathbf{3 3}$ が生成していた。そ こで， $\alpha$-ケト酸 33 の開裂を検討したところ，塩基 性条件下で過酸化水素を用いた場合に望みの変換が 定量的に進行することがわかった．ただし，オゾン 酸化の再現性がそしかったため, 31 を用いてさら 

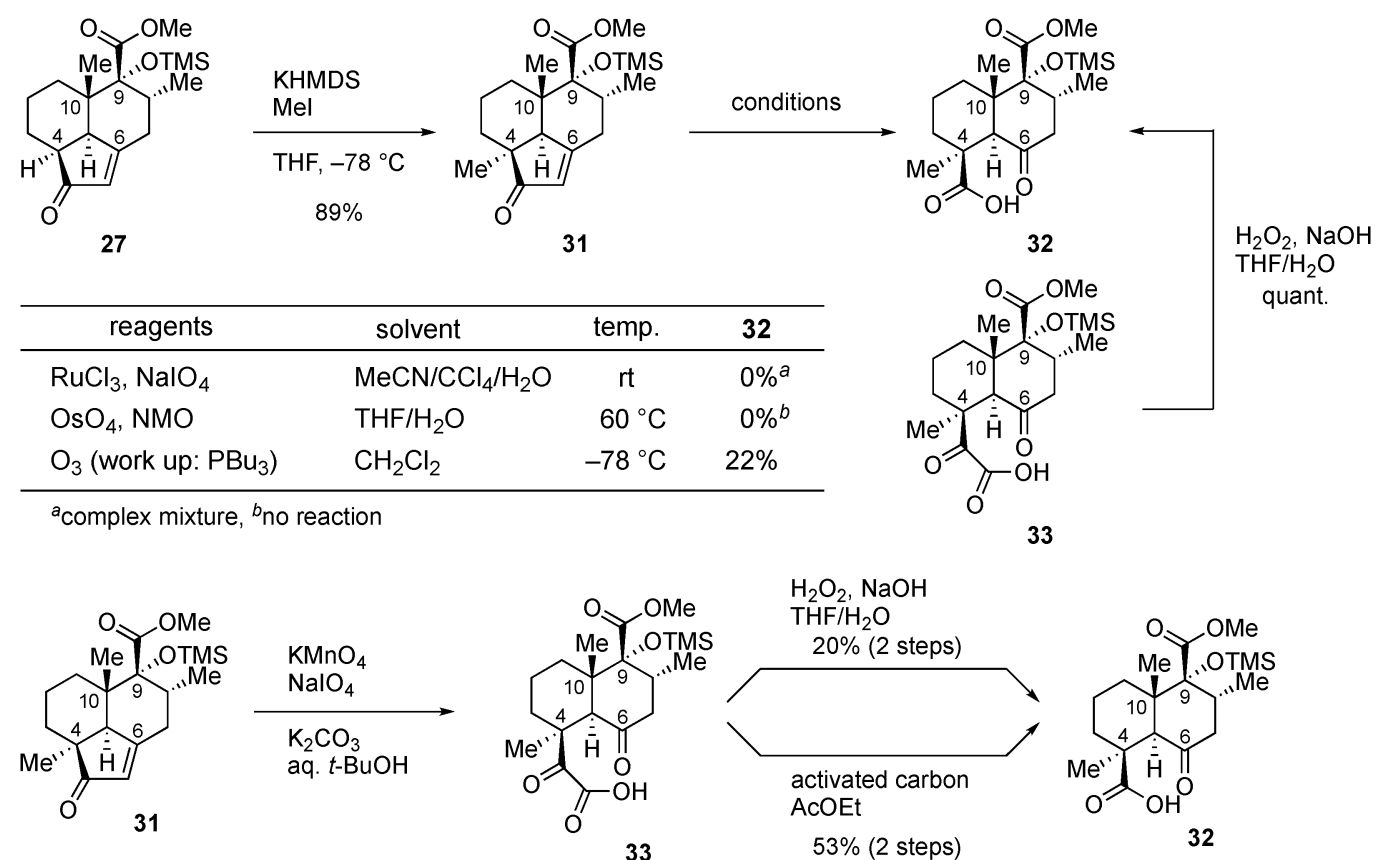

Scheme 4. Oxidative Cleavage of Cyclopentenone

に反応条件のスクリーニングを続けた. その結果, 過マンガン酸カリウムを用いると $\alpha$-ケト酸 33 が主 生成物として得られることを見い出した。この $\alpha$-ケト酸 33 を過酸化水素で処理すると, 残留して いた微量の Mn 塩のために大量の酸素が発生し た。そこで，Mn 塩を取り除く目的で $\alpha$-ケト酸 33 を活性炭で処理すると，予期せぬ脱カルボニル化が 進行して望みのカルボン酸 32 が得られることを見 い出した．なお，製造元の異なる 4 種の活性炭を比 較したが，反応性の違いはみられなかった．現在の こころ反応機構の詳細は不明だが，結果として 2 工 程收率 $53 \%$ でカルボン酸 32 を得ることができた。

次に, ケトカルボン酸 32 を水素化ホウ素ナトリ ウムで還元してから, 混合酸無水物経由でラクトン 26 へ導いた (Scheme 5).13) ここで，第三級アル コールを配向性基としてメチルエステルのみを選択 的に還元することを考え，TMS 基を除去した。 $\alpha$-ヒドロキシエステル 34 の化学選択的な還元は, 塩化メチレン中 $-23^{\circ} \mathrm{C}$ で Red-Al を処理した場合 に実現可能であった。ただし，アルミナート中間体 35 の分解が遅いため, 還元が途中で停止して生じ たアルデヒド $\mathbf{3 6}$ がジオール 37 と一緒に得られたた め，粗生成物を再度同条件下で還元する必要があっ た. ジオール 37 を水素化ナトリウムとトシルイミ ダゾールを用いてエポキシド 25 へと導いた後，臭
化銅存在下，Grignard 試薬 $\mathbf{3 8}$ を作用させることに より, 16,17) マルビイン（24）を光学活性体として初 めて化学合成することに成功した. ${ }^{18)}$

\section{4. 類縁天然物の全合成}

共通中間体のエポキシド 25 を利用して，C9 位側 鎖部の異なる類縁天然物の合成に着手した (Scheme 6)。エポキシド 25 をリチウムアセチリド で開環して二炭素増炭した。得られたホモプロパル ギルアルコール 38 を Ye らの金触媒を用いた酸化 的ラクトン化反応 ${ }^{19)}$ の条件下に付すことで，シレニ ン C (39) を合成できた. ${ }^{10)}$

一方，シロキシ基を持つ Grignard 試薬20)で三炭 素ユニットを導入した後, TBS 基の除去と TEMPO 酸化 ${ }^{21)}$ を行いマルラクトン（41）に導い た. ${ }^{3)}$ また, 水酸化リチウムによりマルラクトン （41）を加水分解することで，マルラン酸（42）が 収率 $84 \%$ で得られた. ${ }^{3)} 2$ 位に TMS 基を持つフラ ンは過酸により位置選択的に酸化できることが知ら れている。 ${ }^{22)}$ 本知見を利用するため，エポキシド 25 を Grignard 試薬 34 で開環した。得られた TMS マ ルビイン 43 に $m$-CPBA を作用させると, 期待通 りマルバッシュ F (44) が収率 57\%で得られた. ${ }^{23)}$

次に, マルビイン (24) のフラン環部の酸化を経 て，マルリブアセタール (3), マルリブアセタール A $(52)$ ，デセルチン（50）への変換を試みた 

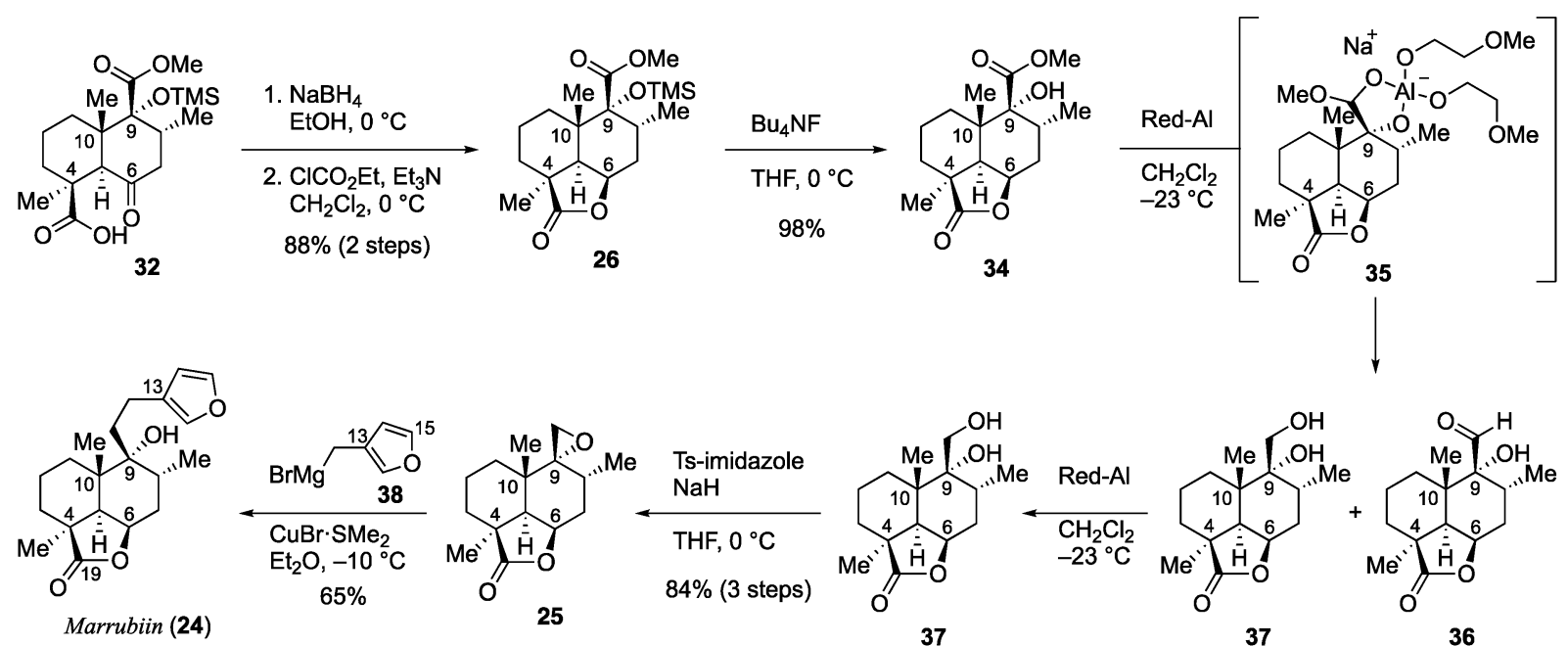

Scheme 5. Synthesis of Marrubiin (24)
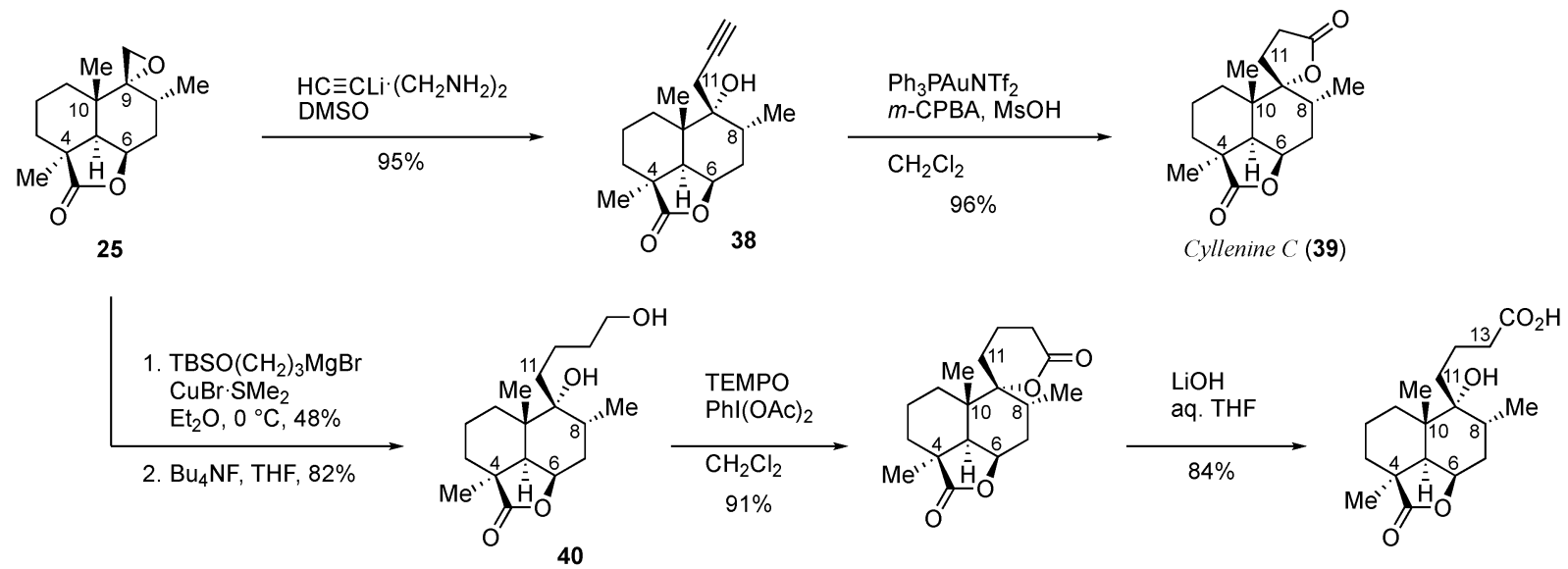

Marrulactone (41)

Marrulanic Acid (42)

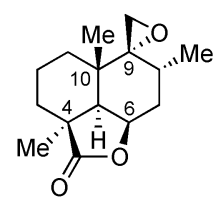

25

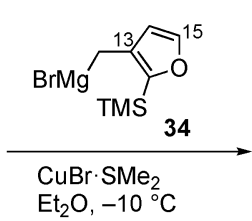

$76 \%$

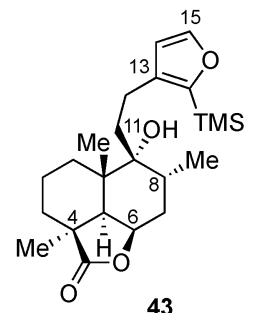

43

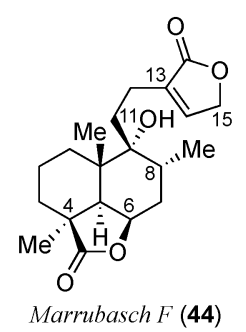

Scheme 6. Syntheses of Cyllenine C (39), Marrulactone (41), Marrulanic Acid (42), and Marrubasch F (44)

(Scheme 7)。マルビイン（24）に対してジクロロ メタンとエタノールの混合溶媒中, ピリジン・ $\mathrm{HBr}_{3}$ を作用させると，ビスアセタール $\mathbf{4 5}$ が 4 種の 異性体混合物（シス：トランス $=2 ： 1 ）$ として生 成した. 四酸化オスミウムによるジヒドロキシ化 は，シス配置のエトキシ基を持つ化合物 2 種に対し てのみ面選択的に進行し, ${ }^{24,25)}$ トリオール 47 と 48 を混合物として与えた，なお，未反応のトランス配
置の原料は回収され，エタノール中で PPTS を作 用させることで異性体比 2:1 のビスアセタール 45 に変換・再利用可能であった.

トリオール 47 と 48 の混合物をトシル酸で処理す ると，マルリブアセタール（3） と， C13， 14，15, 16 位異性体 $\mathbf{5 1}$ が得られた。分離した生成物の立体 化学は NOESY 実験により確認し，マルリブアセ タール（3）の初の全合成を達成することができ 

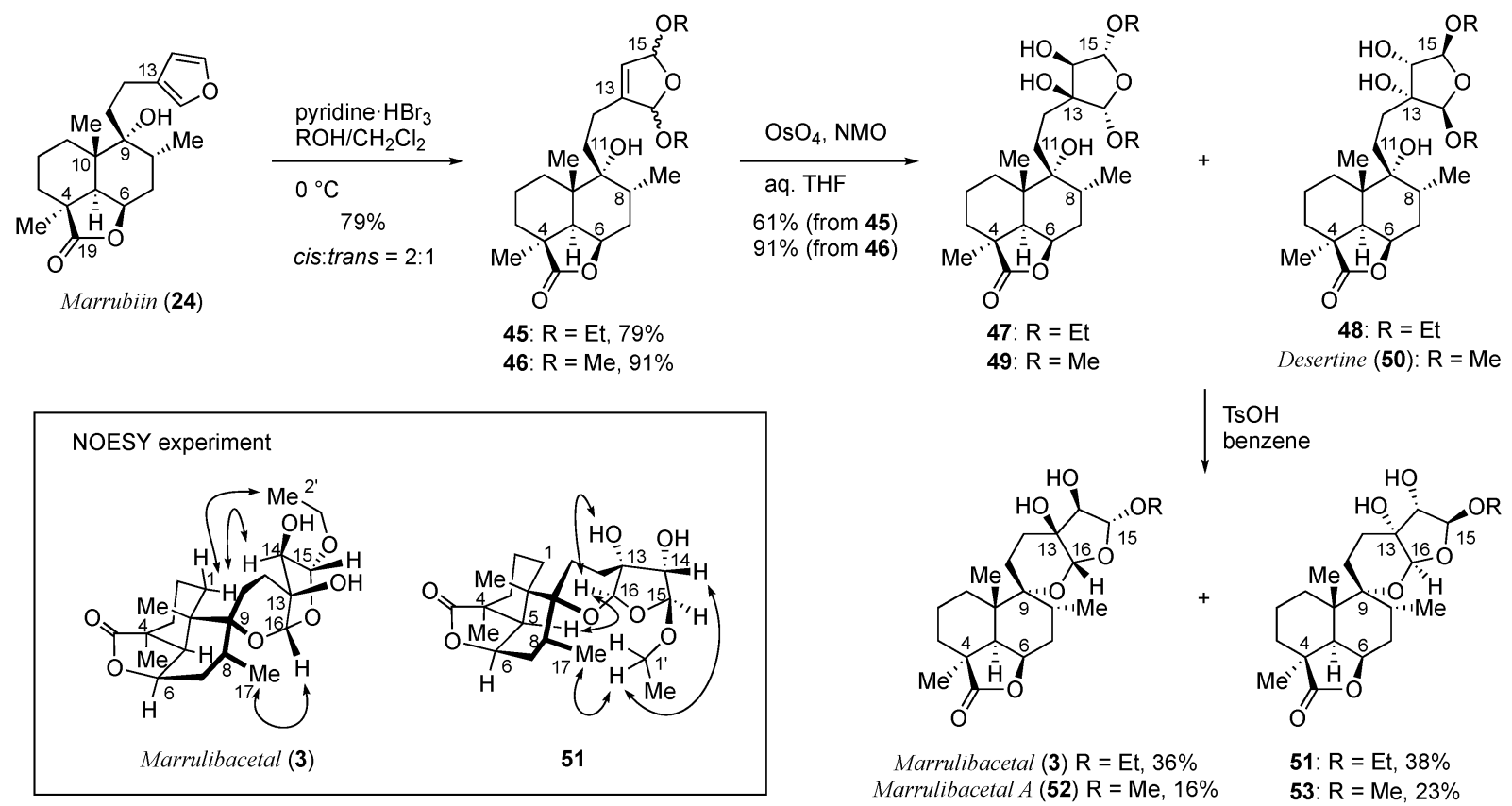

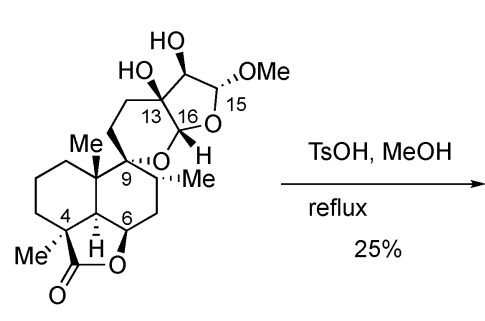

Marrulibacetal A (52)

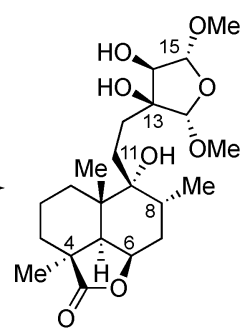

49

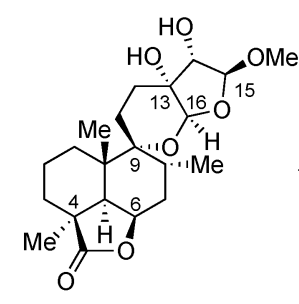

53

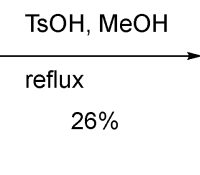

$26 \%$

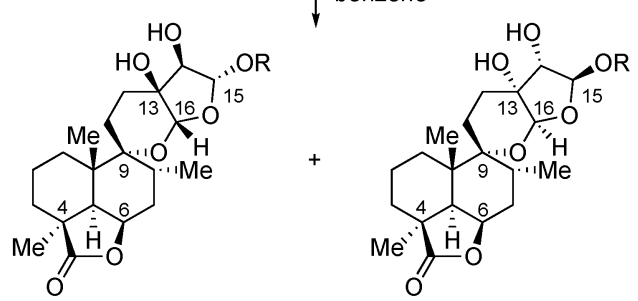

51: $R=E t, 38 \%$ 53: $\mathrm{R}=\mathrm{Me}, 23 \%$

Scheme 7. Syntheses of Marrulibacetal (3), Marrulibacetal A (52), and Desertine (50)

た. ${ }^{3)}$

マルビイン (24) からマルリブアセタール

への変換を踏襲し，フラン環部の酸化の際の溶媒を エタノールからメタノールに代えることで，マルリ ブアセタール A (52) が合成できた. ${ }^{26)}$ その途上, トリオール 49 と 50 の一方が, 立体配置未決定の天 然物デセルチン（50） の NMR スペクトルと完全に 一致することがわかつた. ${ }^{26)}$ 筆者らは, デセルチン （50）の立体化学を決めようとしたが，この段階で デセルチン（50）と異性体 49 を分離できなかった. そこで，単離したマルリブアセタール A （52）と 異性体 53 をそれぞれ，トシル酸存在下メ夕ノール 中で還流したところ，マルリブアセタール A (52) からはトリオール 49, 化合物 53 からはデセルチン （50）が得られた. 以上より，デセルチン（50）の 立体配置を Scheme 7 に示したものに決定できた.

おわりに

本稿では，筆者らの研究の中から新規キラル合成
ブロックの創製を基盤とするテルペノイドの合成に ついて概説した４種のキラル合成ブロックは，エ ステルや多重結合などの官能基を併せ持つことか ら，合成したい化合物に応じて変換方法を柔軟に選 択できる利点を持つ. 本稿の後半にてまとめたキラ ル合成ブロック 6 からのラブダンジテルペンラクト ン類の合成に加え，他 3 種のキラル合成ブロック 4,

5，6，7 からの天然物合成を完成させることで，同 ブロックの汎用性が示されると考えている. 現在は 合成したラブダンジテルペンラクトン類をリード化 合物として創薬化学研究を展開しており，有用な医 薬品リード化合物の創出を介して薬学の発展と人類 の健康に貢献したい.

謝辞本研究は, 名古屋市立大学大学院薬学研 究科薬品合成化学分野において行つたものであり, ご指導頂いた中村精一教授に厚く御礼申し上げま す。また, 共同研究者の名古屋市立大学大学院医学 
研究科, 大矢 進教授, 鬼頭宏彰博士に深謝申し上 げます。本研究をともに遂行した赤堀禎紘博士，澤 山侑季氏，坂上友花梨氏，斎藤彩有里氏，大田陽野 氏，近藤直記氏，鈴木浩太氏を始め，所属研究室の 学生諸氏に感謝します。本研究をご支援頂きました 日本学術振興会科学研究費補助金 (16K08171, 19K06999), 公益財団法人内藤記念科学振興財団, 有機合成化学協会塩野義製薬研究企画賞に心より感 謝いたします。

\section{利益相反＼cjkstart開示すべき利益相反はない}

\section{REFERENCES}

1) Sholichin M., Miyahara K., Kawasaki T., Chem. Pharm. Bull., 33, 1756-1759 (1985).

2) Gao X.-M., Pu J.-X., Huang S.-X., Lu Y., Lou L.-G., Li R.-T., Xiao W.-L., Chang Y., Sun H.-D., J. Nat. Prod., 71, 1182-1188 (2008).

3) Rigano D., Aviello G., Bruno M., Formisano C., Rosselli S., Capasso R., Senatore F., Izzo A. A., Borrelli F., J. Nat. Prod., 72, 14771481 (2009).

4) Akahori Y., Yamakoshi H., Sawayama Y., Hashimoto S., Nakamura S., J. Org. Chem., 79, 720-735 (2014).

5) Saito S., Yamakoshi H., Nakamura S., Heterocycles, 99, 1086-1094 (2019) .

6) Akahori Y., Yamakoshi H., Hashimoto S., Nakamura S., Org. Lett., 16, 2054-2057 (2014)

7) Tang Y., Li N., Duan J.-A., Tao W., Chem. Rev., 113, 5480-5514 (2013).

8) Yamakoshi H., Sawayama Y., Akahori Y., Kato M., Nakamura S., Org. Lett., 18, 34303433 (2016).

9) Sakagami Y., Kondo N., Sawayama Y., Yamakoshi H., Nakamura S., Molecules, 25, 1610 (2020).

10) Karioti A., Skopeliti M., Tsitsilonis O., Heilmann J., Skaltsa H., Phytochemistry, 68, 1587-1594 (2007).
11) Rigano D., Grassia A., Borrelli F., Aviello G., Piozzi F., Bruno M., Arnold N. A., Capasso R., Senatore F., Planta Med., 72, 575-578 (2006).

12) Popoola O. K., Elbagory A. M., Ameer F., Hussein A. A., Molecules, 18, 9049-9060 (2013)

13) Mangoni L., Adinolfi M., Laonigro G., Caputo R., Tetrahedron, 28, 611-621 (1972).

14) Sugihara T., Yamada M., Ban H., Yamaguchi M., Kaneko C., Angew. Chem. Int. Ed. Engl., 36, 2801-2804 (1997).

15) Yamanaka M., Nakamura E., J. Am. Chem. Soc., 123, 1703-1708 (2001).

16) Welch S. C., Rao A. S. C. P., Lyon J. T., Assercq J.-M., J. Am. Chem. Soc., 105, 252257 (1983).

17) Araki S., Butsugan Y., Bull. Chem. Soc. Jpn., 56, 1446-1449 (1983).

18) Cocker W., Cross B. E., Duff S. R., Edward J. T., Holley T. F., J. Chem. Soc., 2540-2548 (1953)

19) Shu C., Liu M.-Q., Sun Y.-Z., Ye L.-W., Org. Lett., 14, 4958-4961 (2012).

20) Nemoto H., Fujita S., Nagai M., Fukumoto K., Kametani T., J. Am. Chem. Soc., 110, 2931-2938 (1988).

21) Hansen T. M., Florence G. J., Lugo-Mas P., Chen J., Abrams J. N., Forsyth C. J., Tetrahedron Lett., 44, 57-59 (2003) .

22) Kuwajima I., Urabe H., Tetrahedron Lett., 22, 5191-5194 (1981).

23) Zhang J.-S., Zou Y.-H., Zhao J.-J., Chen Y., Bao J.-M., Tang G.-H., Phytochem. Lett., 16, 241-244 (2016).

24) Barbier C., Gagnaire D., Vottero P., Bull. Chem. Soc. Chim. Fr., 2330-2338 (1968).

25) Hönel M., Mosher H. S., J. Org. Chem., 50, 4386-4388 (1985).

26) Zaabat N., Hay A.-E., Michalet S., Darbour N., Bayet C., Skandrani I., Chekir-Ghedira L., Akkal S., Dijoux-Franca M.-G., Food Chem. Toxicol., 49, 3328-3335 (2011). 